症例

内視鏡的摘出の試みにより食道穿孔を生じた有鈎義歯誤飲の 1 例

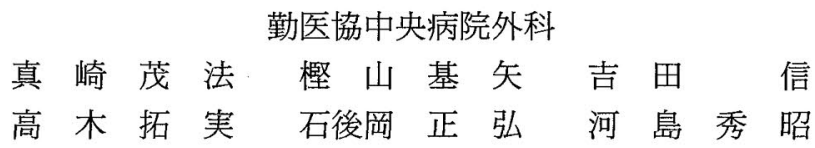

症例は54歳，女性．義歯を誤飲し当院受診．上部消化管内視鏡検査を施行，胃前庭部 に有鈎義歯を認めた．内視鏡的摘出を試みたが抵抗あり，下部食道に数 $\mathrm{mm}$ の穿孔を生 じた。縱隔炎を発症し保存的治療を開始したが縦隔膿瘍となり開腹にて胃内異物除去・ 食道穿孔部縫合閉鎖・大網充填・縦隔・胸腔ドレナージ術を施行した。術後高熱，炎症 反応高値が続き食道の縫合不全を併発しドレナージに長期間を要した。治療に難渋した が保存的治療にて軽快し, 退院となった，今回の症例をふまえ，消化管異物とりわけ有 鈎義歯の適切な治療方針について文献的考察を加え報告する.

索引用語：義歯, 食道穿孔, 内視鏡治療

緒言

有鈎義歯は消化管異物の中でも最も内視鏡的摘出が 困難なものとされ食道穿孔等の合併症発生率も高いと 報告されている11-3). 今回われわれは誤飲有鈎義歯に 対し内視鏡的摘出を試みるも食道穿孔を生じ，保存的 治療を行うも奏効せず，手術を要した 1 例を経験した ので文献的考察を加え報告する。

\section{症例}

患者：54歳, 女性.

主訴: 義歯誝飲, 腹痛.

家族歴：特記すべきことなし。

既往歴：特記すべきことなし。

現病歴：義歯を䛊飲後, 経過をみたが腹痛を自覚し 翌日当院受診. 上部消化管内視鏡検查を施行, 胃前庭 部に有鈎義菌を認めた. EEMR-tube（幕内チューブ） を用いて摘出を試みるも食道下部で抵抗あり中止し, 義歯を胃内に戻した. その後の観察で食道胃接合部(以 下 EGJ と略記) 直上に数 $\mathrm{mm}$ の穿孔を確認し, 加療目 的に当科入院となった.

来院時現症: 身長 $151 \mathrm{~cm}$, 体重 $75 \mathrm{~kg}$, 血圧 $166 / 100$ $\mathrm{mmHg}$, 脈拍 90 回/分, 体温 $37.4^{\circ} \mathrm{C}$, 貧血なし, 黄疸な し, 胸腹部に異常所見を認めなかった。

2007 年 3 月 6 日受付 2007 年 4 月 20 日採用

〈所属施設住所〉

下007-8505 札璂市東区伏古十条 2 丁目15-1
来院時血液生化学検査所見 : WBC $9,300 / \mathrm{mm}^{3}$ と軽 度上昇以外は異常を認めなかった。

来院時腹部単純 $\mathbf{X}$ 線所見（図 1 ）：上腹部に有鈎義 歯と思われる異物を認めた。

緊急上部消化管内視鏡所見（外来で施行）（図 2）： 胃内に食物残渣は認めなかった。胃前庭部に有鈎義歯 を認めた。スネア, EEMR-tube を用いて摘出を試みる

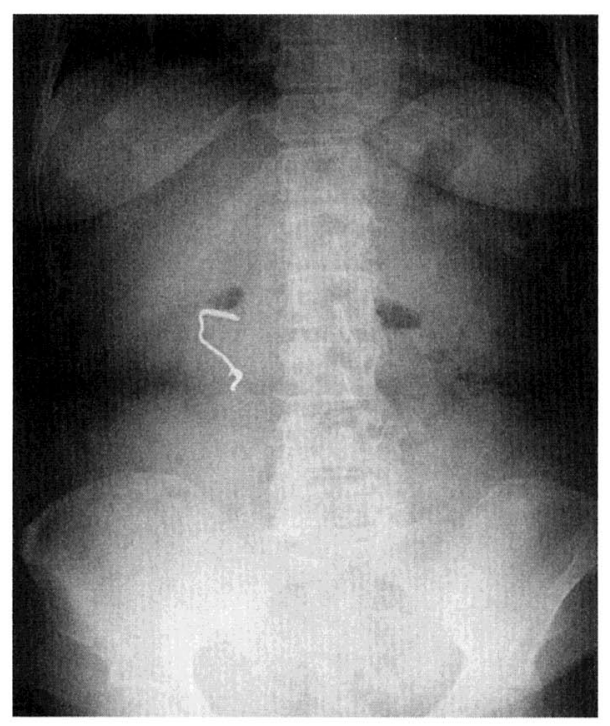

図 1 来院時腹部単純 $\mathrm{X}$ 線所見 : 上腹部に有鈎 義歯と思われる異物を認めた。 


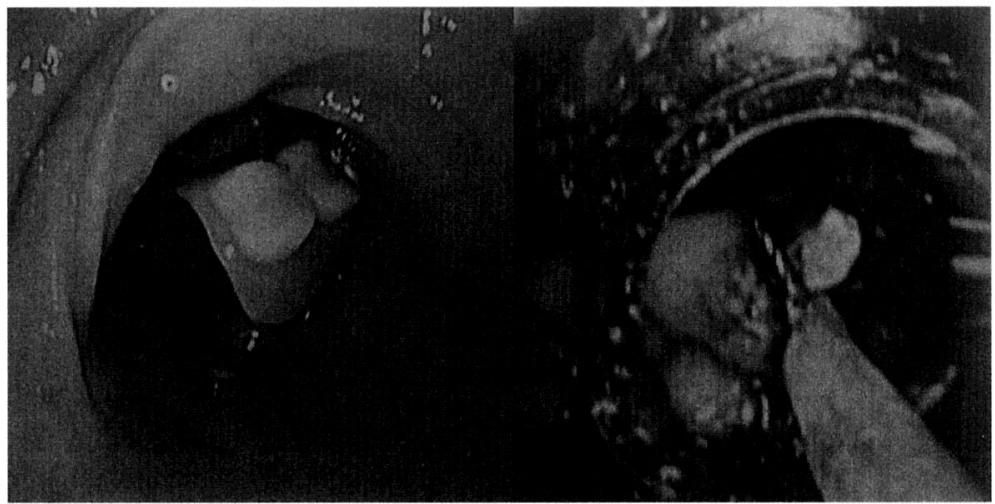

a

b

図 2 緊急上部消化管内視鏡所見：胃前庭部に有鈎義歯を認め（a），スネア・ EEMR-tube を用いて内視鏡的摘出を試みたが(

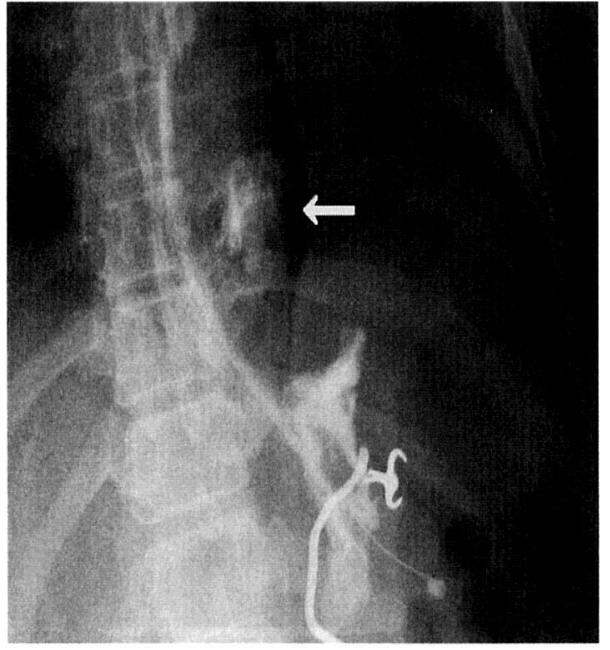

図 3 食道 $X$ 線造影所見 $： \leftarrow て ゙$ 示す部位に食道 からの造影剤の漏出を認めた。

も抵抗あり中止. EGJ 直上に径数 $\mathrm{mm}$ の穿孔を確認し た.

食道 $\mathbf{X}$ 線造影所見 (内視鏡後, 外来で施行) (図 3 )： 造影剤の食道からの漏出を認めた。

肺縦隔 CT 所見（内視鏡後，外来で施行）（図 4)：縦 隔気腫および両側胸水を認めた。

入院後の経過：内視鏡後より発熱を認め, 入院後 38〜 $9^{\circ} \mathrm{C}$ 台の発熱，炎症反応高値が持続した。食道穿 孔・縦隔炎と診断して保存的治療を行い, 炎症が沈静 化したのちに胃内異物除去術を予定した。経鼻胃管， 左胸腅ドレナージ, 中心静脈栄養を行い, 抗菌薬はパ
ニペネム・ベタミプロン，リン酸クリンダマイシンを 用いた。しかし軽快せず，縦隔膿瘍となり第 7 病日に 手術を行った。

手術所見：上腹部正中切開にて開腹，胃体部前壁に 約 $2 \mathrm{~cm}$ の切開をおき胃内異物を除去した. EGJより 約 $3 \mathrm{~cm}$ 口側食道に約 $2 \mathrm{~cm}$ の穿孔部を認め, これを4OPDS-IIにて全層で縫合閉鎖し，大網を縫合部に縫着 した. 縦隔, EGJ 部にドレーンを各 1 本ずつ挿入した。 続いて右側臥位で胸腔鏡下に胸腔内の癒着を剥離し洗 浄，前方・後方にそれぞれ $18 \mathrm{Fr} ， 20 \mathrm{Fr}$ 胸腔ドレーンを 挿入し手術を終えた。

摘出した義歯（図 5 ）：最大径 $3 \mathrm{~cm}$ の鋭利な鈎を持 つ有鈎義歯であった。

術後経過：術後高熱が続き, WBC $10,000 / \mathrm{mm}^{3}$ 前 後, CRP 4〜 $6 \mathrm{mg} / \mathrm{dl}$ で推移した.セフタジジムを使用 していたが第 9 術後病日には喀痰から MRSAを検 出, 塩酸バンコマイシンを併用した。縦隔・EGJ 部ド レーンから少量膿性の排液が続いた。第12術後病日の 縦隔ドレーン造影で食道の縫合不全が明らかとなった (図6).その後も高熱, 炎症反応高值が続き治療に難 渋した。胸水培養でStapylococcus cohnii, Candida albicans, 喀痰培養でMRSA, Pseudomonas Aeruginosa を検出し, それらに対しセフタジジム, 塩酸バ ンコマイシン, 塩酸シプロキサシン, 塩酸ミノサイク リン, 塩酸リンコマイシン, ボリコナゾールで治療を 行った。時間を要したが徐々に炎症は改善し第55術後 病日に綐隔ドレーン抜去となり, 第58術後病日退院と なった。 


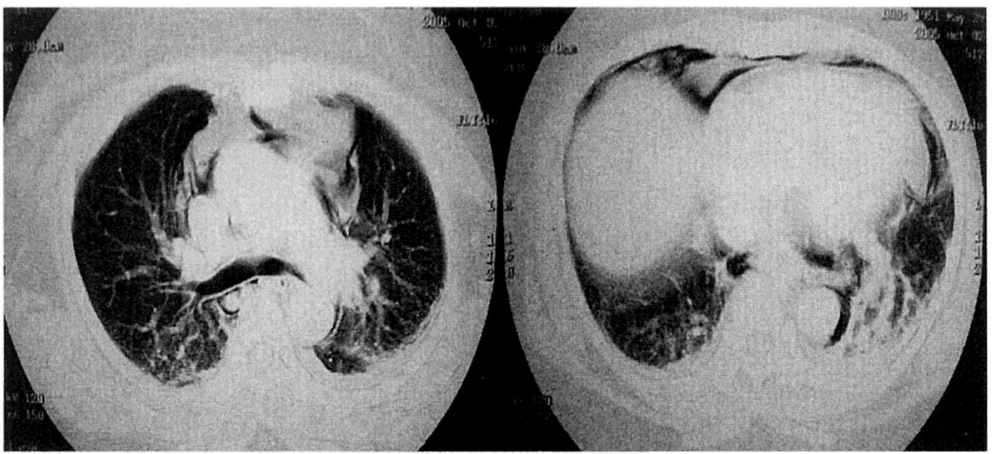

図 4 肺縦隔 CT 所見：縦隔気腫および両側胸水を認めた.

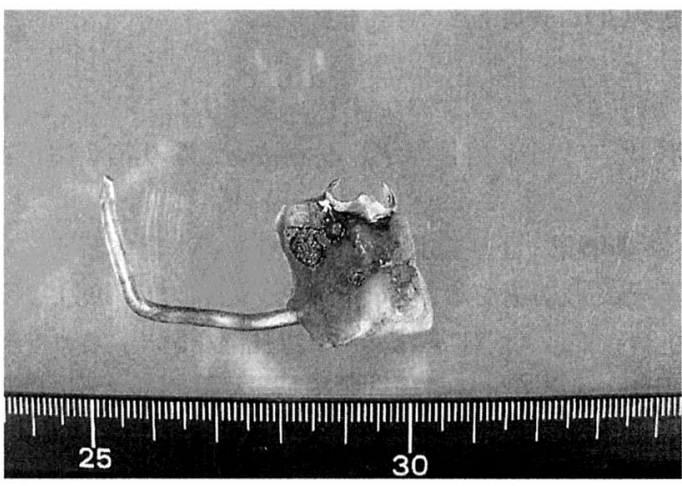

図 5 摘出した義歯：最大径 $3 \mathrm{~cm}$ の鋭利な鈎を持つ有 鈎義歯であった。

\section{考察}

上部消化管異物に対しては多くの場合，内視鏡的摘 出が試みられるが有鈎義歯に関しては尖鋭な鈎により 食道穿孔等の重篤な合併症を起こす危険性が高く上部 消化管異物の中で最も内視鏡的摘出が困難で危険性の 高い疾患であると報告されている 飲は中高年以降に多くみられ，岩田ら ${ }^{2)}$ は食道異物の 784 症例のうち $9.7 \%$ が義歯によるもので年齢のピーク は60歳台であったと報告している，義歯誤飲の基礎疾 患については脳血管障害などによる礖下機能低下，精 神疾患, 喉頭部の術後, 放射線照射後の食道癌3などが 挙げられているが本症例ではこれらの基礎疾患は認め なかった。胃に到達した異物は $80 \%$ 以上は自然排泄が 可能であるとの報告がある4)一方で，義歯を含めた鋭 的異物は合併症を起こす確率が15～35\%と高いため緊 急に摘出を要すると報告されている5゙.

義歯の摘出法としてわれわれが検索しえた限り

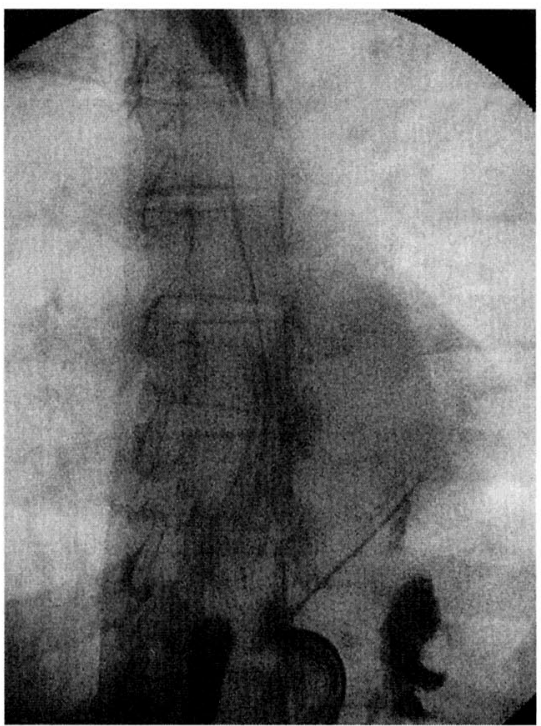

図 6 第 12 術後病日縦隔ドレーン造影：縦 隔ドレーンからの造影で食道が造影され， 食道の縫合不全が明らかとなった。

（1983年～2006年医学中央雑誌) 28例中22例に手術が， 5 例に内視鏡的摘出が施行され，1例は自然排出され たと報告されている(6) 15). 義歯の内視鏡的摘出時の工 夫としてラテックスフード，フォーレイバルーンカテ 一テル，気管内チューブ用カフ等の使用により摘出に 成功した例が報告されている16)17).

本症例では EMR 用透明チューブの中でも最も太い EEMR-tube を用いて内視鏡的摘出を試みたが EGJ 部で抵抗があり食道穿孔を生じた。有鈎義歯の場合そ の大きさにもよると思われるが結果的にはチューブ内 に義歯を収納することができなかった時点で安全に摘 
出ができないと判断し内視鏡的摘出を断念すべきであ ったと深く反省させられた。

食道穿孔の治療方針として Cameron ら ${ }^{18)}$ は破裂が 縱隔内に限局している2）破裂孔を通して食道へドレ ナージがなされている 3 ) 症状が軽い 4) 感染徴候が 軽いことを保存的治療の適応として举げている. 食道 穿孔は総合的判断のもとに保存的治療を選択すべきで あるが，また保存的治療の限界を見極めるのは困難と 報告されて敄り ${ }^{19)}$, 明確な適応基準は示されていない のが現状である，食道穿孔の治療方針は個々の症例に より慎重に決定する必要がある。本症例では胃内に食 物残渣がなく内視鏡的粘膜切除術後等の穿孔症例の対 処に準じて保存的治療を選択したが軽快せず，手術を 要した。すでに綐隔膿瘍に至り重症感染状態となって いたため炎症の遷延, 縫合不全をきたし治療に非常に 難渋した。結果的には当初から手術による摘出を行っ ていれば治療に難渋することはなかったと考えられ る.

有鈎義歯の治療法は十分なインフォームドコンセン 卜のもと, 内視鏡的摘出か手術かあるいは自然排泄を 期待するかを慎重に選択する必要がある．また内視鏡 的摘出に際してはオーバーチューブやフードを用いて 慎重にかつ安全な摘出を心がけ, 安全に摘出できない 場合は内視鏡的摘出に固執しないことが重要と考えら れた。

本疾患の手術後の予後は一般的に良好とされている ものの, 開胸手術後の縫合不全により死亡した例 ${ }^{19)} も$ 報告されており, 致死的な合併症を起こしうることを 念頭におき適切な治療方法を選択することが重要と考 えられた。

\section{結 語}

胃内異物としての有鈎義歯に対し内視鏡的摘出を試 みたが食道穿孔を生じ手術を要した 1 例を文献的考察 を加えて報告した.

なお本論文の要旨は第89回日本臨床外科学会北海道支部 例会にて報告した。

\section{文 献}

1）山本 馨, 前川彦右衛門, 恩地浩二他：わが教室 10 年間の気道扔よび消化管異物症の統計的観察特に摘出困難症例について一, 日気管食道会報 19:222-233, 1968

2）岩田重信, 三嶋由充子, 西村忠郎他：最近10年間 の食道・気管・気管支異物東海地区 7 大学耳鼻咽 候科教室の統計.日気管食道会報 $47: 510-525$,
1996

3）木村哲郎, 湯田厚司, 篠木 淳他：当教室過去21 年間の食道異物症例の集計. 日気管食道会報 $51: 301-305,2000$

4）谷村仲一：消化管異物の対応のしかた. 房本英之 編, FOCUS 消化器 2 腹部救急医療, 中山書店, 東京, 1994, p152--154

5) Vizcarrondo FJ, Brady PD, Nord $H$, et al: Foreign bodies of the upper gastrointestinal tract. Gastrointestinal Endoscopy 29:208210, 1983

6）谷脇 聡, 片网 誠, 渡会長生他：義歯による食 道穿孔の, 2 手術例. 腹部救急診療の進歩 9 : 1021-1023, 1989

7）篠原正一, 田崎大喜, 北尻雅則他: 食道異物除去 術中に惹起された緹隔, 皮下気腫および気胸の 2 例. 臨麻 $13: 419-420,1989$

8）斉藤寛文, 宮脇富士夫, 井出博文他 : 義歯誤飲に よる食道穿孔の 1 治験例. 外科診療 $113: 1079$ 1083, 1989

9）中山尚樹, 吉田昭男, 新垣 馨他: 食道気管瘻を 生じた食道義歯異物症例. 日気管食道会報 40 ： 488-493, 1989

10）仁科雅良, 藤井千穂, 田中 茂他：保存的治療し えた食道穿孔の 1 治験例. ICU と CCU $15: 171$ $-175,1991$

11）大野勝之, 生田目公夫, 池田忠明他：内視鏡的義 歯摘出術による食道損傷の 1 例. 外科晾療 32 : 1024-1027， 1990

12）首藤真理子, 野口 剛, 内田雄三他：外科的に摘 出した食道異物 (有鈎義歯) の1例. 大分医会誌 $21: 18-21,2003$

13）道本 董, 成高義彦, 小川健治他: 緊急手術を要 した有鈎義㐘による食道異物の 1 例. 日腹部救急 医会誌 $23: 561-564,2003$

14）秋定 健, 吉弘 剛, 折田洋造他: 開胸にて摘出 した義歯食道異物症例. 日気管食道会報 $44: 315$ $-319,1993$

15）森脇義弘, 豊田 洋, 杉山 貢他: 緊急開胸開腹 手術で 1 期的食道再建を要した胸部食道異物（有 鈎義歯)の 1 例. 日消外会誌 $39: 277-282,2006$

16) Sykes MT, Schwesinger $W H$ : Safe retrieval of a swallowed denture using a hooded panendoscope. Gastrointestinal Endoscopy $29: 142,1983$ 
17）佐藤邦夫，狩野 敦，折居正之他：上部消化管異 物の内視鏡的摘出についての検討. Gastroenterol Endoscopy 27:695-705, 1985

18) Cameron JL, Kieffer RF, Hendrix TR, et al: Selective nonoperative management of contained intrathoracic esophageal disruptions. Ann Thorac Surg 27 : 404-408, 1979

19）田辺 聡, 宮武一志, 西元寺克禮他：食道異物 穿孔の診断と治療.集中治療 $12 ： 156-159,2000$

\title{
A CASE OF ESOPHAGEAL PERFORATION CAUSED BY ENDOSCOPIC REMOVAL OF AN ARTIFICIAL TOOTH WITH CLASP
}

\author{
Shigenori MASAKI, Motoya KASHIYAMA, Makoto YOSHIDA, \\ Takumi TAKAGI, Masahiro ISHIGOOKA and Hideaki KAWASHIMA \\ Department of Surgery, Kin-I-Kyo Chuo Hospital
}

A 54-year-old female presented after accidentally ingesting her artificial tooth with clasp. We felt a resistance to endoscopic removal which we attempted that left an esophageal perforation of a few millimeters. As mediastinitis developed, we started conservative medical management. After a while, a mediastinal abscess appeared, and we performed an operation to remove the foreign body in the stomach, and to suture shut the esophageal perforation area. At the same time, we also performed omentopexy, as well as drainage of the mediastinal and pleural space. The post surgical condition, with constant high fever and a high rate of an inflammatory response, complicated the failure of the esophageal sutures, which took a long time to drain. This case was very difficult to deal with, but the patient was eventually discharged on the 58th postoperative day, by successful conservative medical management. 